\title{
The Influence of Use of Local Financial Management Information System in Order To Create Transparency and Accountability Financial Management
}

\author{
Wildoms Sahusilawane ${ }^{1 *}$ \\ ${ }^{1}$ Universitas Terbuka, Tangerang, Indonesia
}

\begin{abstract}
This research aims to examine the effect of Regional Financial Management Information System in achieving Transparency and Accountability. The research population involves the head of administration, chief financial officer, treasurer and staff in Ambon and Tual City in Maluku Province with total number are 125 respondents, This research uses purposive sampling as research sample in which it fulfils total of 114 resondents.The questionnaire was tested by using reliability test and validity test. Then, it was continued with classic assumption test contained of multicollinearity test, normality test, and heteroskedastisity test.After that, there was hypothesis test and discussion.

The result showed that that variable the use of Local Financial Management Information System had showed positive and significant impact on the transparency of financial management while the effect of the use of Local financial management information system showed no significant effect on the financial management accountability.
\end{abstract}

Keywords: Local Financial Management Information System, Transparency, Accountability

\section{INTRODUCTION}

Globalization era has seen the rapid advancement and development of technology along with the development of technology-based information system. The advancement and development not only affect the management of a company but also affect accounting information system in a business organization significantly.

The use of information system in organizations has experienced a number of improvement. This is in accordance to Westland and Clark (2000) in Handayani (2005) who claim that the application of information system has dramatically advanced. The improvement, in addition to the demand of modern organizations, is led by society's irresistible needs of information. Information system assists organizations to deliver information promptly, accurately and transparently, as expected by the society. Today's society have embodied a set of modern mindsets - gradually abandoning manual tasks and creating a series of innovations to obtain information.

* Corresponding author. Email address: wildoms.s@gmail.com 
Local government who formulate and implement the policy of APBD (Regional Revenue Budget and Expenditure) are obliged to be transparent and responsible for each of development implementation results. One of the given responsibilities is to provide comprehensive financial information, including regional financial information to public. Accordingly, local governmment are to develop and utilize the advanced information technology to improve the ability to run regional finance and to deliver regional financial information to stakeholders. This intends to conform with the development process based on the principles of good governance.

Nevertheless, a successful information system depends on the convenience and the utilization of the system by the system users as information system technology is applied in a company to assist individuals to perform their tasks. Lucas and Spitler (1999) in a research by Soraya Amalia (2010) opine that the effective use of information technology will positively contribute to individuals' performances. Therefore, individuals in an organization must be able to operate the technology well. One important thing that a company, which applies the information technology, needs to notice is how far the system is able to bring about positive impact in the improvement of performances, individually and collectively.

Accordingly, the government have attempted to create remarkable services to public by establishing information technology in finance or accounting. One of the government's daily implementation of information technology in accounting is regional financial management information system. Financial management information system is an application created by Directorate General of Regional Finance, Ministry of Home Affairs of the Republic of Indonesia in order to accelerate data transfer and optimize data accumulation of regional finance. Financial management information system is an integrated application employed as a tool for local government to improve the effectivity of implementation in various regulations of regional financial management with such principles as efficiency, prudence, effectivity, transparency, accountability and auditability (http://keuda.kemendagri.go.id/sipkd).

Several improvements in regional financial management are accomplished notably in budgeting, accounting and auditing which need top priority so that the financial management is well-maintained. Alongside the implementation of Regional Autonomy, a sufficient information system is necessary for regional financial management in order to administer funds with a transparent decentralization system that is highly accountable to public. Transparency aims at finding out the upside and downside of regional financial management and taking policies based on the outputs of financial reports.

Regional financial management information system is established to aim at several regulations; among them are (1) Government Regulation No. 65 of 2010 on Regional Financial Information System, (2) Government Regulation No. 58 of 2005 on Regional Financial Management, (3) Regulation of Ministry of Home Affairs No. 13 of 2006 on Guidelines to Regional Financial Management, (4) Regulation of Ministry of Home Affairs No. 26 of 2006 on Guidelines to APBD (Regional Revenue Budget and Expenditure) Preparation, and (5) Circular of 
Ministry of Home Affairs No. 900/1199/BAKD (Regional Finance Administration Board) on Technical Guidelines to Implementation of Regional Financial Management Information System and Regional Financial Information System.

Regional Financial Management Information System (SIPKD) in local government is not set up yet to optimally do anything for civil servants or system users. The use of the system to process accounting data and other tasks is not, most of the case, fully accessible for them. Ultimately, the information technology turns out to be a slight drawback for them. Jumili (2005) sets out that, in general, the effectivity of the use and implementation of information system technology depends heavily on the easy access for users to identify, access and interpret the data.

Modern and sophisticated information system has been implemented in numerous organizations with high budget. On the other hand, the implementation of information system is still deemed low and discontinuing and is, therefore, not exploiting its resources. Venkatesh and Davis (2000) in Handayani (2005) state that the low implementation is identified to be caused by productivity paradox, which refers to costly investment in a system with low productivity. The established system should hence be implemented by employees so that the given requirements and goals can be achieved, which in this case refers to superior qualities of publicly-funded services. The concept in this research is Technology Acceptance Model (TAM) which proposes that users tend to operate a system if it is easily operated and does not lead to a number of significant shortcomings.

One of the main aspects in good governance is transparency in managing regional finance. The government create opportunities for all levels of citizens access to financial-related information. Local government's responsibilities are vital for their citizens. Local government are supposed to be citizen-oriented institutions to provide qualified public services and to meet citizens' increasing demand and expectation. Another main aspect in the concept of Government's financial reports is accountability.

Governmental Accounting Standards Board (GASB, 1999) in Concepts Statement No. 1 on Objectives of Financial Reporting states that accountability is the basis of financial reporting in a government which is based on citizens' rights to know and to obtain explanation on collection and implementation of resources. The statement reveals that accountability enables citizens to evaluate government's responsibilities for each of their activities. In addition, Concepts Statement No. 1 asserts that government's financial reporting has the ability to assists users in economic, social and political decision-making by comparing the actual financial performances with the budgeting, evaluating the financial conditions and the operating results, assisting to determine the level of obedience to constitutions related to financial issues and assisting to evaluate the level of efficiency and effectivity.

Mardiasmo (2004) states that transparency refers to government's opennes in providing information related to any activities of public resources management to those who are in need of it. Government has the obligation to provide the financial 
information and other related information which are necessary for decisionmaking.

The current phenomena in the development of public sectors in Indonesia is the increasing demand for accountability of public institutions, be it central or regional. Accountability can be defined as a form of responsibility for the usefulness and failure of implementing a mission of an organization in achieving given purposes and targets through periodically-executed responsibilities (Stanbury, 2003 in Mardiasmo, 2006).

According to Nordiawan (2006), accountability is a prerequisite for individuals' ability to be responsible for resource management and policy implementation which are assigned to reporting entities in order to achieve certain purposes which have been periodically established.

Each of reporting entities has an obligation to report any attempts and results achieved during the implementation of a certain activity sistematically and structurally in one reporting period (Dodi Nordiawan 2006). Accountability is classified into several types, and each of certain information can be relevant in different ways to obtain judgements on accountability.

One of the main aspects in government financial reports is transparency. Transparency refers to the extent to which interested parties, in this case the citizens, have wide and periodical access to any required financial reporting set up by the government.

According to Adrianto (2007), transparency is tremendous and comprehensive openness that accomodates active participants from each level of society in the process of public resource management. Dedi Nordiawan (2006) asserts that transparency relies firmly on the basis of freedom of directly acquiring information related to publicly-funded services for those who are in need of it. Accordingly, transparency can be achieved if the government system in a country grants a set of freedom and openness for its citizens to gain any necessary information in the process of public resource management.

According to the official website of Ministry of Home Affairs of the Republic of Indonesia (http://keuda.kemendagri.go.id/sipkd), Regional Financial Management Information System (SIPKD) is an application set up by Directorate General of Regional Finance, Ministry of Home Affairs of the Republic of Indonesia so as to accelerate data transfer and optimize data accumulation of regional finance. The application is processed by Sub-Directorate of Regional Financial Management Information in Directorate of Regional Financial Implementation and Accountability. It is an integrated application employed as a tool for local government to improve the effectivity of implementation in various regulations of regional financial management with such principles as efficiency, prudence, effectivity, transparency, accountability and auditability.

The implementation of a system and information technology is closely related to the aspects of behaviors since system development is firmly associated with the individuals and organizations as the system users, which in turn leads to the development of an user-oriented system. Lina (2007) states that the success of the implementation of an information system does not only depend on how well the 
system can process a piece of information but also depends on the level of individuals' acceptance of the implementation of the information system.

Furthermore, this research examines the effect of regional financial management information system on the transparency and accountability of regional financial management. The objective of the research is to empirically test the effect of regional financial management information system on the transparency and accountability of regional financial management.

The method of sampling selection applied in this research is purposive sampling. Purposive sampling is a sampling technique of data sources with certain purposes. The sample of the research is the Head of Finance and civil servants as SIPKD (Regional Financial Management Information System) users. Data sources of the research are primary data which are directly obtained from the data field. Data testing method involves correlation and regression analysis with SPSS. The analysis result is presented in descriptive statistics, data quality test, classical assumption test, regression analysis, hypothesis test and discussion.

\section{FINDING AND DISCUSSION}

The number of distributed questionnaires is 125 exemplars to respondents at (Regional Financial Management Work Unit that consists of agencies, boards and offices) in City Government of Ambon and City Government of Tual. The returned questionnaires are 118 exemplars, $94 \%$ out of 125 exemplars. There are 4 unusable questionnaires due to incomplete answers. Therefore, the number of eligible questionnaires for data tabulation is 114 questionnaires which accounts for $93 \%$ out of 125 exemplars. The overview of respondents' profiles can be seen in the following table:

Table 1 Respondents' Profiles

\begin{tabular}{|c|c|c|}
\hline Description & Total & Percentage (\%) \\
\hline Sex: & & \\
\hline a. Male & 43 & $37,7 \%$ \\
\hline b. Female & 71 & $62,3 \%$ \\
\hline Age: & & \\
\hline a. $21-30$ years old & 58 & $50,87 \%$ \\
\hline b. $31-40$ years old & 29 & $25,43 \%$ \\
\hline c. $>41$ years old & 27 & $23,68 \%$ \\
\hline Education: & & \\
\hline a. Master degree & 9 & $7,9 \%$ \\
\hline b. Bachelor degree & 67 & $58,8 \%$ \\
\hline c. Senior High Scholl & 28 & $24,6 \%$ \\
\hline d. Others & 10 & $8,8 \%$ \\
\hline Years of service: & & \\
\hline a. $1-10$ years & 75 & $65,78 \%$ \\
\hline b. $11-20$ years & 23 & $20,19 \%$ \\
\hline c. $21-30$ years & 14 & $12,28 \%$ \\
\hline d. > 30 years & 2 & $1,75 \%$ \\
\hline
\end{tabular}

Source: primary data, 2015 
Based on the sex description, it can be seen that the majority of SIPKD users are females which are 71 people that make up $62,3 \%$, while males only account for 43 people or $37,7 \%$. Based on the age description, most respondents are aged between 21 and 30 years old, who are 58 people (50,87\%). Those aged $31-40$ years old come second, which indicates productive ages at workplace. Based on the education description, most of them have accomplished bachelor degrees -67 people $(58,8 \%)$. The significant number implies the use of SIPKD as a choice in financial management. As for the years of services, most of them have been working from 1 year to 10 years, which is 75 people or $65,7 \%$. These years of services are considered as appropriate years at workplace.

The test on data instrument, which is data quality test that includes validity test, reveals that the value of correlation coefficient of each question along with the total score of each variable is significant at the level of 0,01 (two-tailed). The value indicates that each instrument applied in this research is valid, and the reliability test shows that Alpha coefficient of the variable of SIPKD Use is 0.712, that the variable of Accountability is 0.795 , while the variable of Transparency is 0.676 . Accordingly, the instruments for the whole variables of this research are reliable for the next tests.

Table 2 Result of Reliability Test

\begin{tabular}{cccc}
\hline No & Variables & $\begin{array}{c}\text { Cronbach's Alpha } \\
\text { Value } \\
\text { (Reliability Test) }\end{array}$ & $\begin{array}{c}\text { Factor Loading } \\
\text { (Validity Test) }\end{array}$ \\
\hline 1 & Use of SIPKD & 0,712 & $0,634-0,663$ \\
2 & Accountability & 0,795 & $0,668-0,715$ \\
3 & Transparency & 0,676 & $0,682-0,560$ \\
\hline
\end{tabular}

After the data are tested and proven valid and reliable, the next procedure is to analyze the data in order to test the hypothesis. However, since this research applies multiple regression analysis model, test on the assumptions that base the analysis model need to be done first.

The result of multicollinearity presented in table 3 represents the value of Tolerance and VIF (Variance Inflation Factor). The test result shows that the value of Tolerance is no less than 0,10 , while that of VIF is no more than 10 , which proposes that there is no sign of multicollinearity among the variables (Ghozali, 2006). The result of multicollinearity test can be seen in the following table:

Table 3 Multicollinearity Test

\begin{tabular}{lccc}
\hline \multicolumn{1}{c}{ Variable } & Tolerance & VIF & Description \\
\hline Transparency & 0.999 & 1.001 & No multicollinearity \\
Accountability & 0.999 & 1.001 & No multicollinearity \\
\hline
\end{tabular}

Multiple linear regression test is employed to detect the effect of independent variables on the dependent variable. The effect value of the independent variables on the dependent variables can simultaneously be calculated in multiple regression equation. 
Table 4 Multiple Linear Regression Test

\begin{tabular}{llcc}
\hline & & \multicolumn{2}{c}{ Unstandardized Coefficients } \\
\cline { 3 - 4 } & Model & B & Std. Error \\
\hline 1 & (Constant) & 9.598 & 2.505 \\
& Transparency & .563 & .078 \\
& Accountability & .140 & .105 \\
\hline
\end{tabular}

a. Dependent Variable: Use

The regression equation based on the table is as follows:

$$
Y=9,598+0,563 X_{1}+0,140 X_{2}
$$

Based on the equation, the constant $(\beta 0)$ is 9,598 . This indicates that there is no change in the variable of transparency (X1) and the variable of accountability (X2), which affect the dependent variable. Therefore, the use of SIPKD in the City Government of Maluku is 9,598. Meanwhile, the result of the multiple regression test on the independent variables can be explained as follows:

1. The coefficient value of transparency (X1) that accounts for 0,563 has positive effect on the use of SIPKD (Y). This suggests that the use of SIPKD by civil servants at the City Government rises by 0,563 with an assumption that the other independent variable remains steady.

2. The coefficient value of accountability (X2) that accounts for 0,140 has positive effect on the use of SIPKD (Y). This suggests that the use of SIPKD by civil servants at the City Government rises by 0,140 with an assumption that the other independent variable remains steady.

Table 5 Coefficient of Determination (R2)

\begin{tabular}{ccccc}
\hline Model & R & R Square & $\begin{array}{c}\text { Adjusted } R \\
\text { Square }\end{array}$ & $\begin{array}{c}\text { Std. Error of } \\
\text { the Estimate }\end{array}$ \\
\hline 1 & $.576^{\mathrm{a}}$ & .332 & .320 & 2.454 \\
\hline
\end{tabular}

a. Predictors: (Constant), Accountability, Transparency

Based on the table of coefficient of determination, it can be seen that $\mathrm{R}$ square is 0,332 which indicates that the use of SIPKD is affected by the variables of transparency and accountability with a percentage of $32 \%$, while the remaining $66,8 \%$ is generated by other variables which are not analyzed in this research. 
The Influence of Use of Local Financial Management Information System in Order To Create Transparency and Accountability Financial Management

Table 6 Simultaneous Test Result (F-test)

\begin{tabular}{clccccc}
\multicolumn{8}{c}{ ANOVA $^{\mathbf{b}}$} \\
\hline \multirow{2}{*}{1} & Model & Sum of Squares & df & Mean Square & F & Sig. \\
\cline { 2 - 6 } & Regression & 331.668 & 2 & 165.834 & 27.544 & $.000^{\mathrm{a}}$ \\
& Total & 668.297 & 111 & 6.021 & & \\
& 999.965 & 113 & & & \\
\hline
\end{tabular}

a. Predictors: (Constant), Accountability, Transparency

b. Dependent Variable: Use

Source: primary data, 2015

Based on the above table, the result of the data processing shows that the significance value of F-test is 0.000 . Based on the test criteria, if the probability value is $<0,05, \mathrm{Ha}$ is accepted. It can be concluded that the variables of transparency and accountability simultaneously have significant effect on the use of SIPKD. This is based on the significant value of F-test $=0.000<0,05$. Therefore, higher transparency and accountability lead to higher use of SIPKD.

To figure out the use of regional financial management information system on the regional financial management, partial test is applied with T-test.

\begin{tabular}{|c|c|c|c|c|c|c|}
\hline \multicolumn{7}{|c|}{ Coefficients $^{\mathbf{a}}$} \\
\hline & \multirow[b]{2}{*}{ Model } & \multicolumn{2}{|c|}{$\begin{array}{l}\text { Unstandardized } \\
\text { Coefficients }\end{array}$} & \multirow{2}{*}{$\begin{array}{c}\begin{array}{c}\text { Standardized } \\
\text { Coefficients }\end{array} \\
\text { Beta }\end{array}$} & \multirow[b]{2}{*}{$\mathbf{T}$} & \multirow[b]{2}{*}{ Sig. } \\
\hline & & B & Std. Error & & & \\
\hline \multirow[t]{3}{*}{1} & (Constant) & 9.598 & 2.505 & & 3.832 & .000 \\
\hline & Transparency & .563 & .078 & .563 & 7.255 & .000 \\
\hline & Accountability & .140 & .105 & .103 & 1.333 & .185 \\
\hline
\end{tabular}

a. Dependent Variable: Use

Source : primary data, 2015

The proposed hypothesis is as follows:

H1: The transparency of financial management at the City Government has a positive effect on Regional Financial Management Information System.

The hypothesis is based on the following criteria:

tcalculate $<$ ttable $(\mathrm{df}=\mathrm{n}-2)$ means Ho is accepted.

tcalculate $>$ ttable $(\mathrm{df}=\mathrm{n}-2)$ means Ho is rejected.

The calculation result shows that tcalculate is 7,255 with a significance level of 0,000 . If the significance level is less than $0,05, \mathrm{H} 1$ is accepted, which implies that the use of Regional Financial Management Information System has a vital role in achieving the transparency of financial management at the City Government in Maluku Province.

Meanwhile, T-test is applied to find out the role of regional financial accounting system on the accountability of regional financial reporting. The proposed hypothesis is as follows: 
$\mathrm{H} 2$ : The accountability of financial management at the City Government has a positive effect on Regional Financial Management Information System.

The hypothesis is based on the following criteria: tcalculate $<$ ttable $(\mathrm{df}=\mathrm{n}-2)$ means Ho is accepted. tcalculate $>$ ttable $(\mathrm{df}=\mathrm{n}-2)$ means Ho is rejected

The calculation result shows that tcalculate is 1,333 with a significance level of 0,185 . If the significance level is greater than $0,05, \mathrm{H} 1$ is rejected, which implies that the use of Regional Financial Management Information System has not yet to be fully optimized in achieving the accountability of financial management at the City Government in Maluku Province.

\section{The effect of SIKPD use on the transparency of financial management}

The partial result of the research shows that the use of Regional Financial Management Information System has a significant and positive effect on the transparency of financial management at the City Government of Maluku Province. A better use and development of information technology, which is Regional Financial Management Information System (SIPKD), leads to a better advancement of transparency since it provides information much needed by citizens or public. This is in line with the research by Firmansyah (2008), The Role of Regional Financial Accounting System (SAKD) in Achieving Transparency and Accountability of Regional Government Finance. The finding proposes that the Regional Financial Accounting System has a positive effect on achieving the transparency of regional finance.

\section{The effect of SIPKD use on the accountability of financial management}

The partial test results indicates that the variable of SIPKD use does not significantly affect the accountability of regional financial management. It can be concluded that budgeting plan is arranged with the available information system, and yet the financial reporting cannot be easily accessed by the citizens. Moreover, the financial reporting set up by City Government has not yet to be accurately executed. Accordingly, to improve the accountability of the financial reporting, there need to be well-executed budgeting plan and easily-accessed arrangement of financial reporting. This finding is different from the finding in Firmansyah's research (2008), The Role of Regional Financial Accounting System (SAKD) in Achieving the Transparency and Accountability of Regional Government Finance. The finding proposes that the Regional Financial Accounting System has a positive effect on the transparency of regional financial reporting.

\section{CONCLUSION}

Based on the data analysis, several conclusions can be drawn along with the limitation and the suggestion as follows:

1. Based on the empirical T-test, the variable of the use of Regional Financial Management Information System (SIPKD) on the transparency of financial management at City Governent of Maluku Province is significant. The implementation is highly suggested since with SIPKD the result is widely available and easily obtained by citizens through the given media. 
2. Based on the empirical T-test, the use of Regional Financial Management Information System (SIPKD) on the accountability of financial management at City Government of Maluku Province is not significant. This proves that the respondents do not consider that the financial management at the City Government is fully accountable.

3. Based on the empirical and simultaneous F-test, there is a positive and significant effect of SIPKD use on the transparency and accountability.

This research has extensive implication in the future. It is expected to be beneficial as a reference in accounting in public sector in optimizing the transparency and accountability of organizational financial reporting by using information system.

1. The result of the research is a contribution to the City Government of Ambon and Tual and can be applied as a reference for the use of regional financial management information system that leads to the transparency and accountability of the financial reporting so that the use of information system and the local government's performances can be improved.

2. This research is expected to provide contribution to literature development in public accounting, most notably the use of Regional Financial Management Information System.

The suggestion as a follow-up of this research is as follows:

The upcoming researches are expected to involve other variables. In addition to transparency and accountability, there are other myriads of technical factors that allow and effect the implementation of SIPKD. It is also expected that the upcoming researches engage more sample and do not solely focus on several agencies, boards and offices but on the whole bodies of City and Regency Governments. Last but not least, the instrument needs developing, which is accustomed to the condition and the environment of the observed object.

\section{References}

Adrianto, Nico. (2007). Good Government : Transparansi dan Akuntabilitas Publik melalui e-Government. Palangkaraya : Bayu Media

Amalia, Soraya. (2010). Persepsi Pegawai Pajak Terhadap Pemanfaatan Teknologi Informasi Pada Kinerja Individual.

Bastian, Indra. (2006). Sistem Akuntansi Sektor Publik. Jakarta : Salemba Empat.

Davis, F.D. (1989). Perceived Usefulness, Perceived Ease of Use, and User Acceptance of Information Technology. MIS Querterly, (Online), 13(3), 319-340

Firmansyah. (2008). Peran Sistem Akuntansi Keuangan Daerah (SAKD) Dalam Mewujudkan Transparansi dan Akuntabilitas Keuangan Pemerintah Daerah. Fakultas Ekonomi Universitas Widyatama.

Gade, Muhammad. (1993). Akuntansi Pemerintahan. Lembaga Penerbit FEUI: Jakarta

Ghozali, Imam. (2006). Aplikasi Analisis Multi Variate Dengan Program SPSS (Edisi ke 3). Semarang: Universitas Diponegoro 
Goodhue, D.L. (1995). Understanding User Evaluation of Information System. Management Science, Desember, 1827 -1844.

Handayani, Rini. (2005). Analisis Faktor-Faktor Yang Mempengaruhi Minat Pemanfaatan Sistem Informasi dan Penggunaan Sistem Informasi (Studi Empiris Pada Perusahaan Manufaktur di Bursa Efek Jakarta).

Handoko, T. Hani. (1999). Manajemen (Edisi Kedua) : Yogyakarta : BPFE

Jumaili, Salman. (2005). Kepercayaan Terhadap Teknologi Sistem Informasi Baru Dalam Evaluasi Kinerja Individual. Kumpulan Materi Simposium Nasional Akuntansi VIII, Solo, 15-16 September 2005.

Lina. (2007). Pengaruh Perbedaan Individual dan Karakteristik Sistem Informasi Pada Penerimaan Penggunaan Teknologi Informasi Dalam E-Library. Jurnal Ekonomi dan Bisnis Indonesia, 22.

Mardiasmo. (2002). Akuntansi Sektor Publik. Yogyakarta.

Mardiasmo. (2004). Membangun Akuntabilitas Publik Keuangan Negara (Edisi No. 39). Majalah Media Akuntansi.

Mardiasmo. (2006). Perwujudan Transparansi dan Akuntabilitas Publik Melalui Akuntansi Sektor Publik: Suatu Sarana Good Governance. Jurnal Akuntansi Pemerintah, 2 (1), 1-17.

Nordiawan, Dedi. (2006). Akuntansi Sektor Publik. Jakarta: Salemba Empat

Peraturan Pemerintah Nomor 65 Tahun 2010 tentang Sistem Informasi Keuangan Daerah (SIKD).

Peraturan Pemerintah No. 58 Tahun 2005 tentang Pengelolaan Keuangan Daerah.

Peraturan Menteri Dalam Negeri No. 13 Tahun 2006 tentang Pedoman Pengelolaan Keuangan Daerah

Permendagri No.26 Tahun 2006 tentang Pedoman Penyusunan APBD

Sari, Maria M. Ratna. (2008). Pengaruh Efektivitas Penggunaan dan Kepercayaan Terhadap Teknologi Sistem Informasi Akuntansi Terhadap Kinerja Individual Pada Pasar Swalayan di Kota Denpasar. Buletin Studi Ekonomi. Universitas Udayana.

Surat Edaran Menteri Dalam Negeri No. 900/1199/BAKD tentang Petunjuk Teknis Pelaksanaan Sistem Informasi Pengelolaan Keuangan Daerah dan Sistem Informasi Keuangan Daerah.

http://keuda.kemendagri.go.id/sipkd, accessed Februari 112015 